\title{
Odpowiedzialność odszkodowawcza adwokata w zależności od formy wykonywanego zawodu
}

\section{Uwagi wstępne}

Kwestia odpowiedzialności adwokata $z$ tytulu świadczenia przez niego „wadliwej” pomocy prawnej była już poruszona w literaturze przedmiotu ${ }^{1}$. Opracowania te dotyczyły jednak samych przesłanek odpowiedzialności, kwalifikacji umowy o świadczenie pomocy prawnej oraz - jako że publikowane były one w większości kilkadziesiąt lat temu - odpowiedzialności odszkodowawczej zespołu adwokackiego. W związku z późniejszymi zmianami prawnymi, polegającymi w szczególności na dopuszczeniu przez ustawodawcę do wykonywania zawodu adwokata w nowych formach prawnych, aktualne pozostaje pytanie, czy ramy prawne, w jakich wykonywany jest ten zawód, mogą mieć wpływ na charakter, a przede wszystkim zakres odpowiedzialności adwokata? W rozważaniach niniejszych pominięto więc problematykę zasad określających zakres odpowiedzialności adwokata wykonującego zawód samodzielnie, w ramach

1 A. Zieliński, Odpowiedzialność odszkodowawcza adwokata i zespołu adwokackiego, Palestra 1986, nr 9, s. 8 i n.; S. Garlicki, Charakter prawny zespołu adwokackiego i stosunku łaczacego adwokata z zespołem, Palestra 1964, nr 4, s. 1-5; J. Kruszewska, Odpowiedzialność odszkodowawcza adwokata i zespołu adwokackiego, Palestra 1988, nr 1-2, s. 3-12; S. Janczewski, Pełnomocnictwo procesowe $w$ zespole adwokackim, Palestra 1968, nr 4 , s. 6-17. 
kancelarii. Wynika to $\mathrm{z}$ faktu, że kwestia ta nie budzi większych wątpliwości; adwokat za szkodę spowodowaną wadliwą pomocą prawną odpowiada w sposób nieograniczony, osobiście i wprost. Skupiono się natomiast na pozostałych formach prawnych wykonywania zawodu adwokata oraz podjęto próbę przybliżenia sytuacji prawnej „nieudolnego” prawnika w kontekście obowiązku odszkodowawczego powstałego w związku $\mathrm{z}$ błędem w sztuce.

Wskazać należy, że choć od 2000 r. adwokaci wykonujący zawód podlegają obowiązkowemu ubezpieczeniu odpowiedzialności cywil$n^{2}{ }^{2}$, to jednak - co istotne - odszkodowanie $z$ ubezpieczenia OC ustala się i wypłaca w granicach odpowiedzialności cywilnej ubezpieczonego. Stąd też w niniejszych rozważaniach pominięto problematykę związaną $z$ umową ubezpieczenia i procesem likwidacji szkody przez zakład ubezpieczeń, w szczególności pominięta została problematyka dochodzenia przez poszkodowanego roszczeń bezpośrednio od zakładu ubezpieczeń na zasadzie actio directa.

\section{Odpowiedzialność adwokata wykonującego zawód w zespole adwokackim}

Jak wynika z uchwały Sądu Najwyższego z 11 marca 1988 r., za szkodę spowodowaną klientowi uchybieniem adwokata, będącego członkiem zespołu adwokackiego, w związku z obowiązkiem starannego działania przy wykonywaniu zlecenia udzielenia pomocy prawnej odpowiedzialność ponosi wyłącznie zespół adwokacki³

W uzasadnieniu swego stanowiska Sąd podkreślił, że to wyposażony w podmiotowość prawną zespół adwokacki (art. 10 ustawy Prawo o adwokaturze ${ }^{4}$ j jest stroną umowy o świadczenie pomocy prawnej (zlecenia); jedynie przez osoby fizyczne - adwokatów, którzy świadczą usługi dla zespołu adwokackiego, podmiot ten realizuje

2 Art. 8a ustawy z 26.05.1982 r. - Prawo o adwokaturze (tekst jednolity Dz.U. z 2002 r. Nr 123, poz. 1058).

3 Uchwała SN - Izba Cywilna z 11.03.1988 r., III CZP 12/88, OSNCP 1989, nr 6, poz. 98, s. 31; Palestra 1988, nr 10, s. 112.

4 Ustawa $z$ 26.05.1982 r. - Prawo o adwokaturze (tekst jednolity Dz.U. z 2002 r. Nr 123, poz. 1058 - dalej pr. adw.). 
nałożone umową obowiązki. Jedynym węzłem prawnym, łączącym adwokata $z$ klientem-kontrahentem zespołu, jest stosunek pełnomocnictwa, niemodyfikujący bynajmniej treści stosunku zlecania pomiędzy klientem a zespołem, będącego podstawą udzielenia pełnomocnictwa. Co istotne, na kliencie spoczywa obowiązek zapłaty wynagrodzenia wyłącznie na rzecz zespołu adwokackiego; adwokat nie może wypowiedzieć pełnomocnictwa bez zgody kierownika zespołu. Przemawia to - zdaniem Sądu - przeciwko traktowaniu adwokata jako osoby trzeciej (art. 391 k.c.) albo zastępcy (art. 738 k.c.), a więc nie uzasadnia odpowiedzialności adwokata wobec kontrahenta zespołu.

O ile prezentowane stanowisko Sądu rozstrzygnęło dość jednoznacznie podstawowy dylemat co do tego, „kto odpowiada wobec klienta", to wydaje się, że przytoczone wyżej orzeczenie, wbrew pozorom, nie wyjaśnia wszystkich mogących się pojawić wątpliwości. Wciąż jako aktualne jawią się bowiem pytania, czy wobec popełnienia przez adwokata błędu w sztuce $z$ roszczeniem regresowym przeciwko nieudolnemu prawnikowi może wystąpić zespół adwokacki; czy adwokat w jakikolwiek sposób może ponieść odszkodowawcze konsekwencje swojego zawinionego zachowania?

Aby odpowiedzieć na to pytanie, należy wskazać, że odpowiedzialność zespołu adwokackiego podlegać będzie ogólnym przepisom regulującym reżim odpowiedzialności ex contractu (art. 471 k.c. i n.). Przyjęcie stanowiska, że adwokat nie jest zastępcą, oznacza, że wskazana odpowiedzialność na zasadach ogólnych nie jest modyfikowana postanowieniami wymienionego już art. 738 k.c. W doktrynie, przy formułowaniu wykładni przepisu art. 474 k.c. ${ }^{5}$, panuje powszechny pogląd, że o podstawie i zakresie tej odpowiedzialności regresowej pomocników (i „zastępczych wykonawców”), za których dłużnik odpowiada wobec wierzyciela (art. 474 k.c.), rozstrzyga każdorazowo treść łączącego ich stosunku prawnego. Taka odpowiedzialność jest więc, co do zasady, dopuszczalna, o ile relacja pomiędzy zobowiązanym $z$ umowy a pomocnikiem (albo „zastępczym

5 Tak T. Wiśniewski [w:] Komentarz do kodeksu cywilnego. Księga trzecia. Zobowiazzania. Tom 1, pod red. G. Bieńka, Warszawa 2007; J. Dąbrowa [w:] System prawa cywilnego, t. III, cz. 1, Ossolineum 1981, s. 775. 
wykonawcą") nie jest stosunkiem czysto faktycznym. Czy więc adwokat występujący w roli swoistego pomocnika zespołu adwokackiego może być w drodze odpowiedzialności regresowej zmuszony do świadczenia odszkodowania na rzecz tegoż zespołu?

Adwokat, członek zespołu, nie jest wprawdzie w tym podmiocie zatrudniony, ale jest w nim zrzeszony ${ }^{6}$. Zespół adwokacki, jako organizacja zawodowa trudniąca się odpłatnym świadczeniem usług prawniczych, posługuje się nim przy wykonaniu umowy. Praca zawodowa adwokata podlega ocenie zespołu adwokackiego; od zgody kierownika zespołu uzależnione jest powierzenie sprawy klienta konkretnemu adwokatowi oraz - o czym już wspomniano wypowiedzenie przez niego pełnomocnictwa (art. 25, 27, 31 pr. adw.). Co więcej, według przepisu art. 24 pr. adw. ${ }^{7}$, przy ustalaniu prawa do świadczeń społecznych (i ich wysokości) pracę w zespołach ustawodawca potraktował jak zatrudnienie, a otrzymane wynagrodzenie - jako wynagrodzenie $z$ tytułu zatrudnienia. Można więc przyjąć, że adwokata łączy $z$ zespołem $z$ jednej strony stosunek członkostwa, określany przepisami ustawy oraz aktami niższego rzędu, w szczególności obowiązkami wynikającymi $z$ regulacji samorządu zawodowego adwokatów, a $z$ drugiej strony umowa o świadczenie usług, niebędąca jednak umową o pracę ${ }^{8}$. Więzi łączącej adwokata $z$ zespołem nie można więc rozpatrywać jedynie $z$ punktu widzenia relacji faktycznych; jest to stosunek prawny, co pozwala stwierdzić, że regres jest możliwy. Należy zatem sformułować tezę, że - tak jak pracownik w stosunku do swojego pracodawcy - tak nieudolny adwokat może ponosić odpowiedzialność regresową, przy czym ustawowe ograniczenie odpowiedzialności pracownika (art. 119 k.p.) nie może mieć tutaj zastosowania, gdyż jest to rozwiązanie szczególne, mające charakter zastrzeżonego w kodeksie pracy wyjątku od reguł ogólnych obowiązujących na podstawie prawa cywilnego.

6 Tak S. Garlicki, op. cit.

7 Zgodnie $z$ art. 170 pkt 8 ustawy z 6.02.1997 r. o powszechnym ubezpieczeniu zdrowotnym (Dz.U. z 1997 r. Nr 28 poz. 153), która weszła w życie $z$ dniem 1.01.1999 r., przepis art. 24 utracił moc w zakresie uregulowanym przez przedmiotową ustawę.

8 S. Garlicki, op. cit., s. 5. 


\section{Specyfika odpowiedzialności adwokata w spółce cywilnej}

Jak wynika $z$ powołanego wcześniej przepisu art. 4a pr. adw., wykonywanie zawodu adwokata w spółce cywilnej możliwe jest wówczas, kiedy jej wspólnicy są wyłącznie adwokatami lub radcami prawnymi, a jedynym przedmiotem działania spółki jest świadczenie pomocy prawnej.

Wobec zmian w przepisach regulujących prowadzenie działalności gospodarczej, w szczególności już wskutek wejścia w życie ustawy - Prawo o działalności gospodarczej ${ }^{9}$, spółki cywilne (w tym te $z$ udziałem adwokatów) mogą być traktowane jedynie jako stosunek obligacyjny, konstytuujący sposób współdziałania w osiągnięciu oznaczonego celu gospodarczego, a nie jako odrębna jednostka organizacyjna o ustalonej prawem podmiotowości.

Spółka cywilna nie ma podmiotowości prawnej, nie jest też przedsiębiorcą. Stąd nie może być samodzielnie stroną umowy o świadczenie pomocy prawnej. Nie zmienia to faktu, że wspólnicy, w ramach określonego umową spółki współdziałania, mogą razem zaciągnąć zobowiązanie o świadczenie pomocy prawnej. Przy tym ewentualnie popełniony przez któregoś ze wspólników przy świadczeniu pomocy prawnej błąd w sztuce może, wobec kształtu kodeksowych uregulowań dotyczących spólki cywilnej, skutkować swoistymi konsekwencjami prawnymi. Swoistość tej regulacji wyraża się w treści art. 864 k.c., według którego za zobowiązania spółki wspólnicy odpowiedzialni są solidarnie, przy czym za zobowiązania spółki uważa się wszelkie zobowiązania powstałe w czasie jej trwania, podejmowane dla osiągnięcia przez nią określonego w umowie celu gospodarczego, a więc i powstałe wskutek nieudolnego wykonania umowy o świadczenie pomocy prawnej. Przepis art. 846 k.c. ma charakter bezwzględnie obowiązujący. Oznacza to, że wspólnicy nie mogą tej kwestii uregulować odmiennie ze skutkiem wobec osób trzecich.

9 Ustawa z dnia 10.11.1999 r. - Prawo działalności gospodarczej (Dz.U. Nr 101, poz. 1178 ze zm.) - uchylona z dniem wejścia w życie Ustawy o swobodzie działalności gospodarczej z 2.07.2004 r. (tekst jednolity Dz.U. z 2007 r. Nr 155, poz. 1095). 
Przyjęta w kodeksie cywilnym formuła prawna dopuszcza natomiast umowną regulację wzajemnych roszczeń regresowych pomiędzy wspólnikami. Co do zasady bowiem, zgodnie z treścią art. 376 k.c., spełniający świadczenie wspólnik może żądać od pozostałych wspólników zwrotu spełnionego świadczenia odszkodowawczego w częściach równych, o ile nie sprzeciwia się temu treść łączącego dłużników stosunku prawnego. Treść stosunku, który w pierwszej kolejności rozstrzyga, czy i w jakiej części wspólnik może domagać się zwrotu spełnionego świadczenia, kształtowana jest przez wspólników w umowie spółki. Zatem celowe wydaje się, aby prawnicy wykonujący zawód adwokata w spółce przez uregulowanie tej kwestii w umowie spółki unikali sytuacji, w której za działania nieudolnego adwokata odpowiedzialność ponoszą także pozostali wspólnicy.

Ukształtowanie solidarnej odpowiedzialności wspólników cywilnej spółki adwokackiej oznacza, że wierzyciel, a więc poszkodowany wskutek wadliwie udzielonej pomocy prawnej, może kierować swoje roszczenie do majątku wspólników w spółce lub do ich majątku osobistego. Na majątek wspólników spółki składają się: własność $\mathrm{i}$ inne prawa majątkowe wniesione $\mathrm{w}$ formie wkładu do spółki oraz to, co zostało nabyte przez wspólników w trakcie trwania spółki w związku z realizacją zakreślonego umową celu. Prawo wspólnika do majątku spółki ogranicza się do prowadzenia za pomocą tego majątku działalności gospodarczej; przy tym majątek ten może być zorganizowany $\mathrm{w}$ formie przedsiębiorstwa $\mathrm{w}$ rozumieniu przepisu art. $55^{1}$ k.c. Odpowiedzialność osobista wspólników za długi spółki, czyli długi powstałe w ramach prowadzonej przez wspólników działalności, jest odpowiedzialnością nieograniczoną i pierwotną. Oznacza to, że wierzyciel nie musi oczekiwać na wynik egzekucji z majątku spółki, aby dopiero w sytuacji, gdy okaże się on niewystarczający, skierować egzekucję do majątku osobistego wspólników. Jednak do egzekucji ze wspólnego majątku wspólników konieczny jest tytuł egzekucyjny wydany przeciwko wszystkim wspólnikom (art. 778 k.p.c.); nie mogą być z niego zaspokajane długi osobiste wspólników ${ }^{10}$. Wspólnik odpowiada jednak swoim

10 Wierzyciel osobisty, który uzyskał zajęcie praw przysługujących wspólnikowi na wypadek wystąpienia ze spółki lub jej rozwiązania, może 
majątkiem osobistym za długi spółki, o ile ich źródłem nie są fakty prawotwórcze $z$ okresu, kiedy nie był wspólnikiem ${ }^{11}$.

Reasumując, odpowiedni kształt umowy spółki mógłby zagwarantować wspólnikom nieudolnego adwokata odzyskanie od niego całego wyegzekwowanego dla osoby trzeciej odszkodowania.

\section{Subsydiarna odpowiedzialność adwokata - wspólnika spółki jawnej}

Spółka jawna jest spółką osobową, która prowadzi przedsiębiorstwo pod własną firmą, a nie jest inną spółką handlową. Każdy wspólnik odpowiada za zobowiązania spółki bez ograniczenia, całym swoim majątkiem, solidarnie $z$ pozostałymi wspólnikami oraz ze spółką ( $z$ uwzględnieniem art. 31 k.s.h. ${ }^{12}$ ). Określenie „zobowiązania spółki" determinowane jest faktem, że to ona, a nie wykonujący w niej zawód adwokata wspólnicy, jest podmiotem zawierającym umowy i stroną kontraktu o świadczenie pomocy prawnej. Zdarzenie prawne, kreujące odpowiedzialność spółki względem poszkodowanego udzieleniem wadliwej pomocy prawnej, nie stanowi więc bezpośredniego źródła jakichkolwiek relacji obligacyjnych pomiędzy wierzycielem a wspólnikami; jego źródła należy upatrywać w art. $22 \S 2$ k.s.h. Adwokat uzyskuje status dłużnika ex lege; jego odpowiedzialność względem wierzyciela spółki jest nieograniczona, solidarna ze spółką. Należy jedynie zasygnalizować, że traktowanie wspólnika jako dłużnika solidarnego nie jest bezsporne, gdyż w literaturze podnosi się, że partner odpowiada za dług cudzy i dlatego zobowiązania spółki i partnerów nie są zobowiązaniami solidarnymi. Zachodzi tutaj jedynie tzw. solidarność odpowiedzialności, co w efekcie pozwala jednak na odpowiednie stosowanie do odpo-

jedynie, wobec bezskuteczności egzekucji z ruchomości wspólnika, przeprowadzonej w ciągu ostatnich sześciu miesięcy, skorzystać $z$ art. 870 k.c. i wypowiedzieć udział w spółce.

11 Wyrok SN z 24 sierpnia 1967 r., II CR 187/67, OSNCP 1968, nr 5, poz. 89.

12 Ustawa z 15.09.2000 r. - Kodeks spółek handlowych (Dz.U. Nr 94, poz. 1037 ze zm.). 
wiedzialności partnerów przepisów dotyczących zobowiązań solidarnych w zakresie, w jakim nie stoi to w sprzeczności z istotą tej odpowiedzialności ${ }^{13}$.

Wprawdzie tak ukształtowana odpowiedzialność spółki w przedmiocie umowy o świadczenie pomocy prawnej może budzić wątpliwości $z$ uwagi na to, że ex definitione to osoba fizyczna wykonuje zawód adwokata (art. 4a pr. adw.); także adwokat, a nie spółka jest ubezpieczony od odpowiedzialności cywilnej (art. 8a pr. adw.); niemniej dopuszczenie przez ustawodawcę wykonywania zawodu adwokata w spółce oraz niebudząca wątpliwości ustawowa konstrukcja spółki jawnej, jako podmiotu zdolnego zaciągać zobowiązania, pozwalają przejść nad tym do porządku dziennego.

Część z komentatorów stoi na stanowisku, że jeżeli do odpowiedzialności zostanie pociągnięta spółka, może ona wystąpić z roszczeniem regresowym wobec wspólnika (adwokata), który naraził ją na szkodę. Można wyrazić jednak stanowisko odwrotne - o ile wspólnik, który spełnił świadczenie odszkodowawcze, powstałe wskutek zaciągniętego przez spółkę zobowiązania, może żądać od pozostałych wspólników oraz od samej spółki jego zwrotu w częściach równych (jeżeli nic innego nie wynika $z$ umowy spółki), to takie roszczenie regresowe nie przysługuje spółce, gdyż odpowiada ona za dług własny ${ }^{14}$.

Także i tu podkreślić należy, że wspólnicy wykonujący zawód adwokata mogą w umowie spółki uregulować kwestię odpowiedzialności za błąd w sztuce odmiennie niż reguła wyrażona w stosowanym na mocy art. 2 k.s.h. przepisie art. $376 \S 1$ k.c. ${ }^{15}$ Mianowicie ukształtować ją mogą w ten sposób, że roszczenia regresowe mogą

13 S. Kowalski, Odpowiedzialność wspólników spółki jawnej za zobowiazzania spółki, Prawo Spółek 2003, nr 8; A. Herbert, Odpowiedzialność wspólników za zobowiązania handlowych spółek osobowych-zagadnienia materialno-prawne, Rejent 2003, nr 6; a także E. Gniewek [w:] Kodeks cywilny. Komentarz, Warszawa 2006, oraz W. Pyzioł [w:] W. Pyzioł, A. Szumański, W. Weiss, Prawo spółek, Kraków-Bydgoszcz 2002.

14 S. Kowalski, op. cit.

15 Ustawa z 23.04.1964 r. - Kodeks cywilny (Dz.U. Nr 16, poz. 93 ze zm.). 
być kierowane tylko do wspólnika winnego błędu w sztuce (oraz do spółki); co więcej, wspólnik niezaangażowany w udzielenie wadliwej pomocy prawnej zostanie w ramach rozliczeń regresowych zwolniony od „ciężaru” odszkodowawczego. Takie rozwiązanie pozwoli uniknąc sytuacji, w której adwokat ponosi nieograniczoną odpowiedzialność za błąd w sztuce swojego nieudolnego partnera. W szczególności chodzi o uniknięcie sytuacji (teoretycznie możliwej), w której poszkodowany wadliwą pomocą prawną klient kieruje egzekucję do majątku niewinnego wspólnika, a ten nie ma możliwości pełnej rekompensaty za utracony wskutek postępowania egzekucyjnego majątek osobisty. Niekiedy w literaturze podnosi się, wobec rzadkich w praktyce klauzul umownych, postulat stosowania per analogiam sposobu rozliczeń regresowych, który jest regułą przy odpowiedzialności ex delictoi, wynikającej z art. $441 \S 3$ k.c. Mogłoby to doprowadzić do uniknięcia tej kuriozalnej sytuacji, w której adwokat odpowiada za innego, nieudolnego prawnika. Stanowisko takie nie jest jednak poparte przekonującą argumentacją.

Należy zaznaczyć, że odpowiedzialność wspólnika odnosi się do wszelkich zobowiązań bez względu na źródło ich powstania; w szczególności dotyczy zarówno zobowiązań cywilnoprawnych, jak i publicznoprawnych, które powstają na mocy umowy, bezpodstawnego wzbogacenia, decyzji administracyjnej, wyroku czy jednostronnej czynności prawnej.

Odpowiedzialność wspólnika, z racji konstrukcji prawnej przyjętej w przepisie art. 31 k.s.h., jest jednak subsydiarna (wtórna). Wierzyciel spółki może bowiem prowadzić egzekucję z majątku osobistego wspólnika wówczas, gdy egzekucja z majątku spółki okaże się bezskuteczna. Za zobowiązania spółki w pierwszej kolejności odpowiada więc spółka posiadanym przez siebie majątkiem.

Należy wskazać, że bezskuteczność egzekucji, o której mowa w art. 31 k.s.h. (poniekąd bliska pojęciu „niewypłacalność”, użytemu w art. $33^{1} \S 2$ k.c.), nie oznacza, że każdy poszkodowany kontrahent spółki musi samodzielnie wszczynać postępowanie egzekucyjne oraz dążyć do niej wszelkimi dopuszczalnymi przez prawo sposobami. Możliwe jest tutaj skorzystanie $z$ szerokiej i zarazem dość liberalnej wykładni sformułowania użytego w art. 298 k.h.; aktualny w tym zakresie pozostaje dorobek piśmiennictwa 
i judykatury ${ }^{16}$. W istocie wierzyciel może egzekwować swoje roszczenie $z$ majątku osobistego wspólnika, gdy jest w stanie powołać się na wynik bezskutecznej egzekucji, prowadzonej przez inny podmiot w stosunku do dłużnej spółki ${ }^{17}$, przy czym wynikać $z$ niej powinno, że bezskuteczność egzekucji dotyczy całego majątku. Nie istnieje jednak konieczność wskazania, że wykorzystano wszystkie sposoby egzekucji ${ }^{18}$.

W judykaturze i doktrynie prawa handlowego wskazuje się także, że wystarczającym dowodem bezskuteczności egzekucji jest sporządzony na żądanie wierzycieli spółki wykaz jej majątku lub jej aktualny bilans ${ }^{19}$, jeżeli $z$ dokumentów tych wynika w sposób niebudzący wątpliwości, że spółka nie posiada majątku wystarczającego do zaspokojenia dłużników. Możliwe także będzie skorzystanie z instytucji wyjawienia majątku (913 k.c. i n.). Podnosi się również, że w razie ogłoszenia upadłości spółki wierzyciel nie jest już zobowiązany wszczynać postępowania egzekucyjnego przeciwko spółce i może je skierować bezpośrednio do majątku wspólników ${ }^{20}$.

Wskazanej wyżej interpretacji przepisu art. 31 k.s.h. towarzyszy regulacja zawarta w kodeksie postępowania cywilnego, gdzie w obecnym brzmieniu przepisu art. $778^{1}$ k.p.c. wskazuje się, że sąd nadaje klauzulę wykonalności przeciwko wspólnikowi (ponoszącemu odpowiedzialność całym majątkiem za zobowiązania spółki), jeżeli egzekucja przeciwko spółce okaże się bezskuteczna, jak również wtedy - co należy podkreślić - gdy ,jest oczywiste, że egzekucja ta będzie bezskuteczna”.

16 Zob. np. orzeczenie SN z 26.06.2003 r., V CKN 416/01, OSN 2004, nr 7-8, poz. 129.

17 T. Dziurzyński [w:] T. Dziurzyński, Z. Fenichel, M. Honzetko, Kodeks handlowy. Komentarz, t. 1, Kraków 1935, s. 480.

18 Zob. orzeczenia SN z 26.04.1938 r., C II 2806/37, PPA 1938, poz. 239 oraz z 9.06.1937 r., C I 1927/36, OSP 1937, poz. 694. oraz orz. SA w Poznaniu z 16.06.1992, I AC 183/92, OSA 1993, z. 4, poz. 28.

19 J. Najmitkiewicz, Kodeks handlowy. Komentarz, Warszawa 1935-1937, t. 1, s. 356; A. Szajkowski [w:] S. Sołtysiński, A. Szajkowski, A. Szumiński, J. Szwaja, Kodeks Handlowy. Komentarz, t. 2, Warszawa 1997-1998 , s. 1452 .

20 Zob. przyp. 11. 
Zauważyć należy, że wprowadzona przepisem art. 31 k.s.h. odpowiedzialność subsydiarna odnosi się do zobowiązań powstałych po zarejestrowaniu spółki; za zobowiązania powstałe wcześniej odpowiedzialność spółki i wspólników będzie solidarna, ale pierwotna (art. 31 § 3 k.s.h.). Natomiast osoba przystępująca do spółki odpowiada za zobowiązania spółki powstałe przed dniem jej przystąpienia (art. 32 k.s.h.).

Kontrahent spółki, dochodzący odszkodowania za szkodę powstałą wskutek wadliwie udzielonej pomocy prawnej, może więc wnieść powództwo przeciwko samej spółce, ewentualnie przeciwko spółce i jednemu wspólnikowi bądź wszystkim wspólnikom. Co więcej, zanim prowadzona przeciwko spółce egzekucja okaże się bezskuteczna, wierzyciel może wystąpić z powództwem przeciwko wspólnikowi (art. 31 § 2 k.s.h.). Praktycznie jednak, wobec zawartego $\mathrm{w}$ art. $778^{1}$ k.p.c. rozszerzenia prawomocności materialnej wyroku, sens występowania $z$ powództwem przeciwko wspólnikowi wyczerpuje się w możliwości zabezpieczenia roszczenia w majątku pozwanego adwokata w procesie.

Podkreślić należy, że w związku z faktem, że w postępowaniu „klauzulowym” nie ma możliwości wysłuchania wspólnika, celowe jest, aby wspólnik-adwokat chcący zgłosić określone zarzuty wstąpił do toczącego się przeciwko spółce procesu jako interwenient uboczny (art. 76 k.p.c.), przy czym zgodnie ze stosowanymi odpowiednio $^{21}$ regułami zakreślonymi przez przepis art. $375 \S 1$ k.c. adwokat w takiej sytuacji bronić się może zarzutami, które przysługują mu osobiście względem wierzyciela. Nadto zgodnie $z$ art. 35 § 1 k.s.h. wspólnik (pozwany z tytułu odpowiedzialności za zobowiązania spółki) może także podnieść wszelkie zarzuty przysługujące spółce względem wierzyciela ${ }^{22}$.

21 Na mocy art. $22 \S 2$ k.s.h.

22 Sąd Apelacyjny w Białymstoku w wyroku z 26.10.2004 r., III CZP 41/04, Prok. i Pr. 2005, nr 3, s. 32 stwierdził, że upływ terminu przedawnienia przeciwko spółce komandytowej w czasie toczenia się sprawy wniesionej przez wierzyciela przeciwko wspólnikom może być skutecznie podnoszony przez wspólników na podstawie art. 35 § 1 w zw. z art. 103 k.s.h. 
Przedstawiona wyżej koncepcja odrębności jurydycznej zobowiązań spółki i wspólników za zobowiązania handlowych spółek osobowych skłania do wniosku, że - co do zasady - terminy przedawnienia roszczeń $\mathrm{w}$ stosunku do tych podmiotów biegną samodzielnie. Wydaje się jednak, że wskutek odpowiednio stosowanego przepisu art. 372 k.c. zaistnienie zdarzenia powodującego przerwanie biegu przedawnieniu roszczenia (jego zawieszenie) $\mathrm{w}$ stosunku do jednego $\mathrm{z}$ partnerów nie spowoduje takiego skutku $\mathrm{w}$ odniesieniu do przedawnienia roszczenia przeciwko innym partnerom lub spółce. $Z$ odmienną sytuacją będziemy mieli do czynienia w momencie, kiedy następuje przerwa lub zawieszenie przedawnienia roszczenia względem spółki; wtedy z uwagi na akcesoryjność odpowiedzialności partnera reguła wynikająca $z$ art. 372 k.c. nie znajdzie zastosowania ${ }^{23}$.

Dodatkowo można zasygnalizować, że zgodnie $z$ niedawną uchwałą Sądu Najwyższego tytułowi egzekucyjnemu wydanemu przeciwko spółce jawnej, opatrzonemu na podstawie art. $778^{1}$ k.p.c. w klauzulę wykonalności przeciwko wspólnikowi tej spółki, sąd nie może nadać klauzuli wykonalności w trybie art. 787 k.p.k. przeciwko jego małżonkowi ${ }^{24}$.

\section{Odpowiedzialność partnera w spółce partnerskiej}

\section{Uwagi ogólne}

Kwestia odpowiedzialności odszkodowawczej adwokata będącego partnerem w spółce partnerskiej za błąd w sztuce czy raczej za powstałą przy świadczeniu pomocy prawnej szkodę została uregulowana specyficznie w art. 95 k.s.h.

W świetle tego przepisu partner nie ponosi odpowiedzialności za zobowiązania spółki powstałe w związku z wykonywaniem przez

23 A. Herbert, op. cit.; zob. także orzeczenie SN z 8.05.2008 r., V CSK 573/07, Biuletyn SN 2008, nr 7.

24 Uchwała Sądu Najwyższego - Izba Cywilna z 12.05.2005 r., III CZP 21/05, Orzecznictwo Sądu Najwyższego Izba Cywilna 2006, nr 4, poz. 58. 
pozostałych partnerów wolnego zawodu w spółce, jak również za zobowiązania spółki będące następstwem działań lub zaniechań osób zatrudnionych przez spółkę na podstawie umowy o pracę lub innego stosunku prawnego, które podlegały kierownictwu innego partnera przy świadczeniu usług związanych z przedmiotem działalności spółki (art. $95 \S 1$ k.s.h.). Artykuł ten jest przepisem szczególnym w stosunku do przepisów art. 22 oraz 31-34 k.s.h., kształtujących odpowiedzialność wspólników spółki jawnej, a stosowanych odpowiednio na podstawie odesłania zawartego w przepisie art. 89 k.s.h. Poza wskazanym w przepisie art. 95 k.s.h. wyłączeniem odpowiedzialność spółki i partnerów jest ukształtowana tak jak w spółce jawnej.

Wskazać należy, że pomimo z pozoru jasnej redakcji przepisu art. 95 k.s.h., jego stosowanie w praktyce może kreować szereg wątpliwości. Budzi je już fakt, czy wskazane w cytowanym przepisie ograniczenie odpowiedzialności dotyczy zarówno odpowiedzialności ex contractu, jak i ex delicto. Przeważa opinia, że przepis ten odnosi się do obu reżimów odpowiedzialności ${ }^{25}$, choć w literaturze można spotkać stanowisko odmienne. Zaznaczyć należy, że w przypadku odpowiedzialności ex delicto spółka odpowiada za wszelkie czyny niedozwolone swojego partnera, a to wskutek stosowanego odpowiednio (na mocy art. $33^{1}$ k.c.) przepisu art. 416 k.c., przy czym zdolność deliktowa spółki dotyczy jedynie zachowań partnerów uprawnionych do reprezentacji (niepozbawionych tego uprawnienia na podstawie umowy spółki lub w drodze uchwały wspólników na mocy art. 96 k.s.h.) ${ }^{26}$.

Odnosząc się do odpowiedzialności kontraktowej, podkreślić należy, że w cytowanym przepisie mowa jest o zobowiązaniach spółki, gdyż to ona jest podmiotem zawierającym we własnym imieniu i na własny rachunek umowę $z$ klientem. Oczywiście przedmiot działania spółki musi korespondować z określonymi prawem

25 E.J. Wrześniak, Spółka partnerska ze szczególnym uwzględnieniem spółek adwokatów i radców prawnych, Kraków 2000.

26 W. Pyzioł, A. Walaszek-Pyzioł, Kilka uwag na temat odpowiedzialności spółki partnerskiej i partnerów, [w:] Odpowiedzialność cywilna. Księga pamiątkowa ku czci profesora Adama Szpunara, Kraków 2004. 
ramami „wykonywanego w spółce” wolnego zawodu, w szczególności zawodu adwokata (art. 4a pr. adw.). Stąd też zawierana $z$ klientem umowa, co do zasady, dotyczy tych zachowań, do podjęcia których zobligowany może być adwokat. Podnosi się jednak słusznie, że przedmiotem umowy mogą być także zachowania, które są niekoniecznie zastrzeżone dla adwokatów czy radców prawnych (porada, opinia prawna). W literaturze dominuje więc opinia, że spółka może się zobowiązywać do wszelkich zachowań zakreślonych pojęciem danego wolnego zawodu ${ }^{27}$.

Pewne wątpliwości może budzić węzeł prawny, który wiąże kontrahenta spółki $z$ adwokatem świadczącym faktycznie pomoc prawną, gdyż przedmiotowa kwestia nie została wprost wyartykułowana w przepisach k.s.h. Jednak już po głębszej analizie omawianych przepisów wydaje się, że kontrahent spółki nie jest powiązany $\mathrm{z}$ partnerem żadnym stosunkiem prawnym (poza stosunkiem pełnomocnictwa procesowego, o ile zachodzi taka potrzeba). Formułuje się w tym zakresie tezę, że jest on (w myśl art. 474 k.c.) wykonawcą zlecenia, którym spółka posługuje się przy wykonywaniu swoich obowiązków umownych ${ }^{28}$.

\section{Odpowiedzialność za błędy własne partnera}

Jak wynika $z$ przepisu art. 95 k.s.h., partner nie ponosi odpowiedzialności za zobowiązania spółki powstałe wskutek wykonywania wolnego zawodu, określonego w umowie spółki, przez innego partnera. Za zobowiązania powstałe wskutek wykonywania zawodu adwokata (radcy) odpowiedzialność ponosi ten partner, $z$ którego zachowaniem łączy się powstała szkoda, a przede wszystkim - co istotne - w pierwszej kolejności sama spółka. Rozpatrując ten pro-

27 Specyficznym odstępstwem od tej reguły jest zawód notariusza, gdzie zgodnie $z$ art. 4 § 3 ustawy z 14.02.1991 r. - Prawo o notariacie (Dz.U. $\mathrm{Nr} 16$, poz. 91 ze zm.) w przypadku prowadzenia kancelarii notarialnej na zasadach spółki partnerskiej „każdy z notariuszy dokonuje czynności notarialnych we własnym imieniu i ponosi odpowiedzialność za czynności przez siebie dokonane".

28 W. Pyzioł, op. cit., s. 581. 
blem z punktu widzenia poszkodowanego, należy zaznaczyć, że może on dochodzić zaspokojenia swych roszczeń od spółki (w pierwszej kolejności), następnie od partnerów, którzy spowodowali szkodę; przyjmuje się bowiem, że ich odpowiedzialność jest solidarna (art. $89 \mathrm{w} z w . z$ art. $22 \S 1$ k.s.h.).

Powtórnie należy podkreślić, że traktowanie partnera jako dłużnika solidarnego jest problematyczne, gdyż w literaturze podnosi się, że partner odpowiada za dług cudzy i dlatego zobowiązania spółki i partnerów nie są zobowiązaniami solidarnymi, a zachodzi tutaj raczej tzw. solidarność odpowiedzialności ${ }^{29}$.

Zauważyć należy, że specyfika tej odpowiedzialności polega na tym, że odpowiedzialność ponosi ten partner, który faktycznie swoim zachowaniem spowodował powstałą szkodę, a nie ten, który za określony projekt czy za danego klienta odpowiada w ramach wewnętrznego rozdziału obowiązków w spółce. Odpowiedzialność poniesie więc tylko ten adwokat, który wykonał zlecenie w sposób wadliwy, a nie ten, któremu sprawę powierzono; nie poniosą jej także inni partnerzy, którzy wykonywali inne zlecenia tego samego klienta. Wykluczone jest więc w takiej sytuacji wysuwanie roszczeń regresowych pomiędzy partnerami wykonującymi w spółce zawód adwokata.

Istotnym problemem może być ustalenie podmiotu odpowiedzialnego w sytuacji, gdy nad jednym projektem pracowało kilku partnerów. Kluczowe może być wówczas zrekonstruowanie procesu decyzyjnego przebiegającego w konkretnej sprawie. Zdarzyć się może, że zobowiązanych będzie kilka osób i każdej z nich zarzucić będzie można błąd w sztuce. Wówczas możliwe będzie formułowanie odpowiednio wzajemnych roszczeń pomiędzy zainteresowanymi partnerami.

Postuluje się niekiedy, aby - wobec trudności związanych z ustaleniem osoby odpowiedzialnego partnera - sąd przyjął domniemanie faktyczne, w myśl którego, odpowiedzialność za szkodę ponosi

29 W efekcie pozwala to jednak na odpowiednie stosowanie do odpowiedzialności partnerów przepisów dotyczących zobowiązań solidarnych. 
kilku lub nawet wszyscy partnerzy ${ }^{30}$. Jest to jednak postulat trudny do zaakceptowania ${ }^{31}$. Należy dodać, że zgłaszana jest także propozycja $^{32}$, aby ustawodawca w sytuacji niemożności ustalenia osoby odpowiedzialnej wprowadził do kodeksu odesłanie do ogólnych reguł odpowiedzialności właściwych dla spółki jawnej ${ }^{33}$. Postulowana zmiana nie tylko spowodowałaby przerzucenie ciężaru dowodowego na spółkę, ale doprowadziłaby także do całkowitej zmiany, przyjętej w k.s.h. konstrukcji spółki partnerskiej, gdyż ograniczenie odpowiedzialności partnerów za zobowiązania spółki byłoby nie regułą, jak dziś, ale wyjątkiem ${ }^{34}$.

Podkreślić należy, że postulowany powszechnie w piśmiennictwie akt podziału odpowiedzialności pomiędzy partnerów ${ }^{35}$, którym wewnątrz spółki przypisane są konkretne działy aktywności spółki i wynikające $z$ tego obowiązki, nie ma znaczenia $z$ punktu widzenia uprawnionego do dochodzenia świadczeń odszkodowawczych poszkodowanego kontrahenta. Regulacja zawarta w art. 95 k.s.h. ma charakter bezwzględnie obowiązujący, a odpowiedzialność partnerów nie wynika $z$ porozumień pomiędzy partnerami, choćby najbardziej porządkujących i precyzyjnych, a $z$ faktycznych działań lub zaniechań konkretnych osób. Jedyna możliwa, umowna modyfikacja odpowiedzialności, która wywoływałaby skutki względem osoby trzeciej, polegać mogłaby na rozszerzeniu odpowiedzialności partnera, który zgodnie z przepisem art. 95 ust. 2 k.s.h., mógłby w każdej sytuacji odpowiadać jak partner spółki jawnej.

30 S. Sołtysiński [w:] S. Sołtysiński, A. Szajkowski, A. Szumiński, J. Szwaja, op. cit., s. 784-785.

31 E.J. Krześniak, op. cit., s. 283.

32 Wzorem odpowiednika niemieckiego.

33 M. Asłanowicz, Treść umowy spótki partnerskiej, PPH 1998, nr 12.

34 E.J. Krześniak, op. cit., s. 281.

35 J. Jacyszyn, Wykonywanie wolnych zawodów w Polsce, Warszawa 2004, s. 193; M. Asłanowicz, Pozycja, s. 27. 


\section{Odpowiedzialność za błędy osób podlegających kierownictwu adwokata}

Podobnie jak w przypadku odpowiedzialności partnera za własne działanie, odpowiedzialność partnera za zachowania osób mu podległych będzie zachodziła, o ile partner ten w danej sprawie faktyczne występował, tj. kierował osobą, która spowodowała swoim wadliwym zachowaniem szkodę. Wątpliwości może budzić użyte w przepisie art. $95 \S$ k.s.h. sformułowanie „kierownictwo” partnera. Przyjąć należy, że to pojęcie obejmuje wszelkie formy podległości służbowej. Za błąd pracownika jednak odpowie tylko ten partner, który nadzorował go przy obsłudze konkretnego zlecenia, nawet wówczas, gdy w świetle wewnętrznego podporządkowania osoba ta „przypisana była” innemu partnerowi. Wyłączenie odpowiedzialności partnerów nie dotyczyłoby więc postępowania osób podlegających tylko „ogólnoorganizacyjnemu” kierownictwu partnera, niezaangażowanego w wykonanie zlecenia.

Kontrowersje budzi natomiast to, jak należy rozumieć użyte w przepisie art. $95 \S 1$ k.s.h. sformułowanie „Związanych z przedmiotem działalności spółki”. Czy wyłączenie subsydiarnej odpowiedzialności partnera za zobowiązania spółki, powstałe w związku z działaniem lub zaniechaniem osób zatrudnionych przez spółkę, które podlegały kierownictwu innego partnera przy świadczeniu usług, dotyczy tej samej sfery znaczeniowej, co w przypadku użytego w tym przepisie sformułowania „w związku $\mathrm{z}$ wykonywaniem zawodu"? Większość komentatorów uznaje, że przepis art. 95 k.s.h odnosi się do postępowania personelu spółki, które dotyczy usług związanych z przedmiotem działalności spółki zakreślonym w umowie spółki ${ }^{36}$, a więc nie tylko wtedy, gdy owe działania (zaniechania) pozostawały w związku $\mathrm{z}$ wykonywaniem wolnego zawodu przez partnera. Kluczową kwestią jest więc to, jak zostanie ukształtowany przedmiot działania spółki, który może być ujęty ogólnie („,świadczenie pomocy prawnej”) jak i określony węziej (np. „obsługa prawna podmiotów gospodarczych”). Za zobowiązania spółki, powstałe wskutek zachowania personelu pomocniczego, które 
wykraczają poza zakres statutowego przedmiotu działalności spółki, partnerzy i spółka odpowiadają na zasadach ogólnych, tak jak w spółce jawnej.

Swoisty problem może zaistnieć w sytuacji, gdy działania powodujące szkodę były działaniami personelu, któremu określone zadanie powierzył jeden $\mathrm{z}$ partnerów, w sprawie, którą adwokat prowadzi poza spółką (np. partner spółki trudniącej się prawną obsługą podmiotów gospodarczych prowadzi sprawę o podział majątku). Podkreślić w tym miejscu należy, że partnerzy przez sam fakt członkostwa w spółce nie wyzbywają się uprawnień do zawierania umów o świadczenie pomocy prawnej poza spółką. W literaturze powszechnie akceptowany jest pogląd, że radca prawny może świadczyć pomoc prawną zarówno w spółce, jak i poza nią. Wydaje się oczywiste, iż prezentowane stanowisko odnosi się także do zawodu adwokata. W tego typu sytuacjach zarówno spółka, jak i (pozostali) partnerzy zwolnieni będą oczywiście od odpowiedzialności w stosunku do poszkodowanego klienta.

Wskazać należy, że użyty w przepisie art. 91 k.s.h. termin „zatrudnienie” należy rozumieć szeroko, w szczególności obejmuje on nie tylko umowę o pracę, lecz również umowę zlecenia i inne umowy o świadczenie usług (art. 750 k.c.). W skład „pracowników” zaliczyć należy odpowiednio aplikantów, prawników nieposiadających uprawnień adwokata, pracowników technicznych itp.

\section{Odpowiedzialność adwokata pozostającego poza strukturami spółki}

Interesującą kwestią jest to, na jakiej zasadzie odpowiadają wobec klienta adwokaci, którzy wadliwą pomocą prawną spowodowali szkodę, a nie są partnerami spółki, lecz jedynie $z$ nią współpracują, Poza tym do rozstrzygnięcia pozostaje problem, czy przepis art. 95 k.s.h. ma jakąkolwiek doniosłość prawną w odniesieniu do relacji spółka-klient-działający w zastępstwie spółki adwokat.

Adwokat pozostający poza spółką nie jest stroną umowy o świadczenie pomocy prawnej; jest nią spółka, która jedynie powierza wykonanie swoich obowiązków adwokatowi. Stąd - zgodnie z ogól- 
nymi zasadami odpowiedzialności kontraktowej37 - przyjmujący zlecenie (spółka partnerska) ponosi odpowiedzialność za czynności swojego zastępcy (art. 474 k.c.), przy czym należy podkreślić, że możliwość zastąpienia spółki podmiotem z zewnątrz wynikać musi z umowy, ewentualnie wprost $z$ przepisu ustawy (tak jak w przypadku art. 91 pkt 3 k.p.c. i zawartej tam substytucji procesowej) ${ }^{38}$.

Spółka prawnicza, która posługuje się osobą spoza grupy partnerów oraz osób w niej zatrudnionych, może zwolnić się od odpowiedzialności za działania takiego podmiotu (adwokata), powiadamiając klienta o osobie zastępcy w wykonaniu zlecenia (o ile substytucja jest dopuszczalna). Wówczas za szkodę wywołaną brakiem należytej staranności w wykonaniu powierzonego zlecenia będzie odpowiadał jedynie adwokat faktycznie występujący w sprawie (zastępca, substytut). Zastępca odpowiedzialny jest za wykonanie zlecenia zarówno wobec dającego zlecenie, jak i wobec podmiotu powierzającego mu je zastępczo do wykonania - spółki (art. 738 § 2 k.c.). Spółka może wówczas odpowiadać wobec klienta jedynie za brak należytej staranności w wyborze zastępcy, choć w przypadku powierzenia wykonania zlecenia adwokatowi, a więc $z$ założenia profesjonaliście, jest to wysoce problematyczne (art. $738 \S 1$ k.c.). Warto zauważyć, że solidarna odpowiedzialność przyjmującej zlecenie spółki oraz adwokata-zastępcy może zachodzić jedynie wówczas, gdy spółka odpowiada na zasadzie ryzyka (przy niedozwolonej substytucji lub braku zawiadomienia), nie zaś wtedy, gdy odpowiada na podstawie $\S 1$ za winę w wyborze ${ }^{39}$.

37 Nic nie stoi jednak na przeszkodzie, aby pozostający poza spółką adwokat odpowiadał wówczas także na podstawie zarzutu sformułowanego ex delicto (art. 415 k.c.), jeżeli oczywiście taki zarzut można będzie względem adwokata wyprowadzić. Fundamentalną kwestią będzie rozstrzygnięcie dylematu, czy niezachowanie należytej staranności przy świadczeniu pomocy prawnej jest kwestią winy czy bezprawności.

38 Kwestia utrwalonej praktyki jako trzecia przesłanka zwolnienia się z odpowiedzialności (art. $738 \S 1$ k.c., w zw. $z$ art. 751 k.c.) nie będzie tu, z uwagi na specyfikę umowy o świadczenie pomocy prawnej, zachodziła.

39 P. Machnikowski [w:] Kodeks cywilny, Komentarz, pod red. E. Gniewka, t. 2, Warszawa 2006. 
Należy zauważyć, że stosunek prawny pomiędzy przyjmującą zlecenie spółką a adwokatem reguluje odrębna umowa. Jak słusznie wskazuje się w literaturze, nic nie stoi na przeszkodzie, aby w umowie o współpracy pomiędzy adwokatem i spółką ta ostatnia zobligowała się do pokrycia strat, które adwokat może ponieść w związku z koniecznością naprawienia szkody klientowi ${ }^{40}$.

Odpowiadając na pytanie, jakie znaczenie w relacji spółka-klient-substytut ma przepis art. 95 k.s.h., zastrzec należy, że odpowiedzialności zakreślonej przepisem tego artykułu podlegać mogą jedynie partnerzy. Stąd przepis ten nie odnosi się w jakikolwiek sposób do osoby „Z zewnątrz”, której powierzono prowadzenie danej sprawy, jeżeli nawet postrzegana jest ona przez klienta spółki jako jej partner (często osoby takie widnieją nawet na firmowej korespondencji spółek). W literaturze podnosi się również problem, czy za szkodę będącą następstwem zachowania adwokata pozostającego poza spółką odpowiedzialny może być tylko ten z partnerów, który pozostawał ( $z$ ramienia spółki w związku $z$ wykonywaniem zlecenia) w kontakcie $z$ adwokatem ${ }^{41}$ Należałoby - jak się wydaje - założyć, że może istnieć odpowiedzialność spółki za działania pozostającego poza strukturą spółki adwokata. Jednakże w związku z tym, że adwokat w wykonywaniu swoich obowiązków podlega jedynie ustawom (art. 1 ust. 3 pr. adw.), kwestia jest wysoce kontrowersyjna. Zwolennicy dopuszczenia odpowiedzialności konkretnego partnera ${ }^{42}$ zgłaszają postulat ścisłej interpretacji art. 1 ust. 3 pr. adw., tzn. nie wykluczają udzielenia adwokatowi (któremu powierzono prowadzenie sprawy w zastępstwie) sugestii co do czasu, miejsca, a także określonych technicznych aspektów wykonania zlecenia.

Można jednak z powodzeniem bronić tradycyjnego stanowiska, że adwokat w wykonywaniu swojego zawodu nie może podlegać niczyjemu kierownictwu. Wydaje się jednak, że rozstrzygającym argumentem jest to, iż warunkiem odpowiedzialności spółki jest bądź nieuprawniona substytucja, bądź brak zawiadomienia klienta o niej albo wina w wyborze zastępcy. Są to więc okoliczności zupeł-

\footnotetext{
40 E.J. Krześniak, op. cit., s. 299.

41 Ibidem.

42 Ibidem.
} 
nie niezwiązane $z$ brakiem należytego „kierownictwa” wykonywanego przez jednego $z$ partnerów nad zastępującym spółkę adwokatem. Stąd też problem ten ma charakter iluzoryczny i rozstrzygnąć go należy w ten sposób, że jeżeli zaistnieją warunki do przyjęcia odpowiedzialności spółki (art. 738 k.c.), to odpowiadać będzie ona na zasadach przyjętych w spółce jawnej, a więc solidarnie ze wszystkimi partnerami (art. 22 w zw. z art. 89 k.s.h.).

\section{Egzekucja odpowiedzialności partnera w spółce partnerskiej}

Poza wyrażonym w art. 95 k.s.h. „przedmiotowym ograniczeniem odpowiedzialności” odpowiedzialność partnera ukształtowana jest w taki sposób jak wspólnika spółki jawnej. Przyjmuje się więc, że odpowiedzialność partnera jest odpowiedzialnością osobistą, solidarną i subsydiarną. Zdaniem niektórych komentatorów w spółce partnerskiej występują wręcz dwa reżimy odpowiedzialności ${ }^{43}$. W pierwszym - za zobowiązania powstałe przy wykonywaniu wolnego zawodu spółka odpowiada całym swoim majątkiem; gdy majątku tego nie wystarczy, odpowiada osobiście odpowiedzialny partner. W drugim reżimie za zobowiązania spółki wiążące się z funkcjonowaniem tego podmiotu jako formy organizacyjno-prawnej wszyscy partnerzy odpowiadają osobiście, solidarnie ze spółką, lecz także subsydiarnie w stosunku do niej. Zobowiązania wynikłe $\mathrm{z}$ funkcjonowania podmiotu $\mathrm{w}$ formie organizacyjno-prawnej to długi związane $z$ administracyjną, bieżącą obsługą adwokatów, np. koszty zakupu lokali czy wyposażenia, wynajmu pomieszczeń, leasingu przedmiotów, koszty obsługi kredytów, a także koszty stosunków pracy personelu pomocniczego itp. Bez znaczenia jest tutaj źródło powstania zobowiązania: umowa, wyrok sądowy, decyzja administracyjna, jednostronna czynność prawna czy bezpodstawne wzbogacenie.

Takie jurydyczne rozwarstwienie owych reżimów niesie ze sobą szereg wątpliwości na etapie dochodzenia roszczeń przed sądem,

43 W. Popiołek, Kodeks spółek handlowych - nowe rozwiazania, Nowy Przegląd Notarialny 2000, nr 5-6. 
a przede wszystkim na etapie ich egzekucji. Kontrahent spółki (klient), pragnący otrzymać kompensatę szkody, może pozwać spółkę, samego partnera odpowiedzialnego za szkodę lub oba te podmioty łącznie. Aktualne jest pytanie, czy poszkodowany klient, polegając na tym, że przepis art. $778^{1}$ k.p.c. przewiduje, że tytułowi egzekucyjnemu wydanemu przeciwko spółce partnerskiej sąd nadaje klauzulę wykonalności przeciwko wspólnikowi ponoszącemu odpowiedzialność całym majątkiem za zobowiązania spółki, może zaniechać pozywania partnera, który dopuścił się błędu w sztuce (ewentualnie odpowiada za zawinione zachowanie podwładnego). W doktrynie przeważa opinia ${ }^{44}$, że powód, chcąc - na wypadek bezskuteczności egzekucji skierowanej przeciwko majątkowi spółki - zaspokoić swe roszczenia z majątku osobistego partnera, winien pozwać obydwa te podmioty. Stąd faktycznie sytuacja poszkodowanego podmiotu jest różna w zależności od rodzaju i okoliczności faktycznych szkody. Powód dochodzący swojego roszczenia $\mathrm{Z}$ innego tytułu niż wadliwa pomoc prawna (np. ze stosunku pracy) będzie zwolniony z konieczności pozywania jakiegokolwiek innego podmiotu poza spółką.

Dla uzasadnienia takiego stanowiska przytacza się następującą argumentację: przede wszystkim sąd, mimo literalnego brzmienia przepisu $778^{1}$ k.p.c., nie powinien nadać klauzuli wykonalności wobec partnera, który nie ponosi odpowiedzialności za zobowiązania spółki. Ustalenie, czy zobowiązanie partnera, stwierdzone wyrokiem, powstało $\mathrm{w}$ związku $\mathrm{z}$ wykonywaniem zawodu adwokata w spółce, czy też wynika z zachowania innego partnera lub osób zatrudnionych w spółce, a podlegających kierownictwu któregoś z partnerów osób, pozostaje w postępowaniu „klauzulowym” poza kognicją sądu. Poszkodowany nie ma na ogół warunków prawnych, aby zrealizować ciążący na nim obowiązek dowodowy i wskazać partnera, który jest odpowiedzialny za szkodę. W postępowaniu tym nie można także przesłuchać partnerów spółki.

Warto zauważyć, że gdyby jednak sąd, kierując się literalną wykładnią przepisu art. $778^{1}$ k.p.c., nadał tytułowi egzekucyjnemu klauzulę przeciwko partnerom, adwokat nieodpowiedzialny za

44 S. Sołtysiński, op. cit. 
powstanie szkody może, „przecząc zdarzeniom, na których oparto wydanie klauzuli wykonalności”, wystąpić z powództwem przeciwegzekucyjnym (art. 840 § 1 k.p.c.).

Wskazuje się także, iż za jednoczesnym wytoczeniem powództwa przeciwko spółce i odpowiedzialnemu za szkodę partnerowi przemawia to, że bez tego powód pozbawia się możliwości zabezpieczenia swojego roszczenia na majątku sprawcy w trakcie procesu.

\section{Odpowiedzialność komplementariusza}

Podobnie jak w przypadku spółki cywilnej, zgodnie $\mathrm{z}$ art. 4 pr. adw. adwokat może wykonywać zawód w spółce komandytowej, o ile wyłącznym przedmiotem jej działalności jest świadczenie pomocy prawnej, przy czym jest to spółka, której wyłącznymi komplementariuszami są adwokaci albo radcy prawni. Sporną kwestią pozostaje, czy w przedmiotowej spółce prawniczej adwokat, w szczególności adwokat podejmujący czynności określone w art. 4 ust. 1 i 2 pr. adw. (świadczący pomoc prawną), może być również komandytariuszem. Jest to o tyle istotne, że wprawdzie komandytariusze, co do zasady, nie mogą reprezentować spółki, to jednak może być im udzielone pełnomocnictwo, a nawet prokura. Władze obu korporacji ${ }^{45}$ stanęły na stanowisku, że nie można wykonywać zawodu adwokata bądź radcy prawnego pod postacią komandytariusza ${ }^{46}$. Stanowisko takie podyktowane jest tym, że ratio legis dopuszczenia wykonywania zawodu w formie spółek osobowych polega na nieograniczonej, co do zasady, odpowiedzialności wspólników względem wierzyciela, kontrahenta spółki. W spółce komandytowej warunki takie spełnia jedynie osoba komplementariusza.

Inaczej wypowiedział się sąd ${ }^{47}$, który w odniesieniu do zawodu radcy prawnego wskazał, iż twierdzenie, że radca prawny może być

45 Adwokackiej i radcowskiej.

46 P. Magnuski, A. Tomaszek, Czy zawód adwokata i radcy prawnego może wykonywać komandytariusz?, Palestra 2001, nr 9-10, s. 10.

47 Sąd Apelacyjny w Białymstoku w post. z 4.04.2001 r., I Aca 96/01, niepublikowane. 
w spółce komandytowej jedynie komplementariuszem, jest sprzeczne $z$ literalnym i niebudzącym wątpliwości brzmieniem przepisu art. 8 ust. 1 Ustawy o radcach prawnych ${ }^{48}$. Wprawdzie kwestia ta jest kontrowersyjna, jednak w związku z jednoznacznym stanowiskiem Naczelnej Rady Adwokackiej wyrok ten nie ma praktycznego znaczenia.

Co istotne, na mocy art. 103 k.s.h. do odpowiedzialności wspólnika spółki komandytowej, będącego komplementariuszem, stosuje się odpowiednio przepisy o spółce jawnej. Specyfika spółki wyraża się przede wszystkim w odmiennych regulacjach dotyczących odpowiedzialności komandytariusza, jednak $z$ uwagi na fakt, że nie może być nim osoba wykonująca zawód adwokata, problematyka ta pozostaje poza zakresem niniejszego opracowania.

\section{Wnioski końcowe}

Jak wynika $z$ poczynionych rozważań, odpowiedzialność adwokata za szkodę wywołaną nieprofesjonalnym zachowaniem może kształtować się odmiennie w zależności od formy prawnej obranej przez wykonującego zawód adwokata.

W przypadku zespołu adwokackiego odpowiedzialność cywilna może dosięgnąć adwokata dopiero wskutek wystąpienia przeciwko niemu z regresem przez odpowiadający za szkodę zespół. A zatem odpowiedzialność ta ma niejako wtórny charakter i jest ograniczona do wysokości kwoty, w jakiej zaspokojono szkodę $z$ majątku zespołu.

W przypadku spółki cywilnej adwokat odpowiada za własne błędy solidarnie wraz innymi wspólnikami; jest to odpowiedzialność „pierwotna”. Adwokat odpowiada do pełnej wysokości zobowiązania, całym swoim majątkiem, także osobistym. Jednak nie oznacza to, że nieudolny adwokat zawsze poniesie pełne konsekwencje swojego zachowania, gdyż wspólnik, który odpowiada solidarnie za dług, może żądać od każdego z pozostałych wspólników zwrotu w czę-

48 Ustawa o radcach prawnych z 6.07.1982 r. (tekst jednolity Dz.U. z 2002 r. Nr 123, poz. 1059). 
ściach równych, tj. takiej części spełnionego świadczenia, jaka wynika $z$ jego podziału przez liczbę wspólników. Tylko odpowiednie ukształtowanie w umowie zasad formułowania roszczeń regresowych spowoduje, że ostatecznie jedynym odpowiedzialnym za powstałą szkodę będzie nieudolny prawnik, który szkodę spowodował (art. 376 k.c.).

W spółce jawnej nieudolny adwokat osobiście odpowie za szkodę tylko wówczas, gdy bezskuteczna okaże się egzekucja odszkodowania $z$ majątku spółki, $z$ tym że i wówczas będzie to odpowiedzialność solidarna z pozostałymi wspólnikami. Regres spółki kierowany do nieudolnego prawnika wydaje się niedopuszczalny. Natomiast odpowiedzialność regresowa pomiędzy wspólnikami w odniesieniu do poniesionej przez nich odpowiedzialności subsydiarnej - co do zasady - oznacza, że poniosą oni konsekwencje odszkodowawcze w równych częściach. Odrębne uregulowanie w umowie spółki przedmiotowej kwestii i konieczność takiego rozliczenia regresowego, aby w efekcie całość wypłaconego odszkodowania obciążyła nieudolnego adwokata, może faktycznie zbliżyć spółkę jawną do partnerskiej, choć tam z zasady (bez konieczności formułowania regresów) za szkodę odpowiada tylko nieudolny partner (choć i w tym przypadku jest to odpowiedzialność subsydiarna).

W przypadku spółki komandytowej odpowiedzialność komplementariusza ukształtowana jest na takich samych zasadach jak w spółce jawnej.

\section{Abstract \\ Civil liability of an attorney for damage brought about by unprofessional behaviour}

The deliberations show that the responsibility of an attorney for damage brought about by unprofessional behaviour will differ depending on the legal form selected thereby. In the case of a group of attorneys, an attorney may be held civilly liable only if the group - responsible for the damage caused - takes recourse against him. Thus, such liability is in a way 
secondary and limited to the amount to which the damage has been covered from the group's assets. In the case of a civil partnership, the attorney is responsible for his own errors jointly and severally with the other partners; this is "primal" liability. The attorney is liable to the full amount of the obligation with all of his assets, also personal. This does not mean, however, that an inept attorney will always be held fully liable for the consequences of his actions, for a partner who is jointly and severally responsible for a debt may demand that the remaining partners return the amount in equal parts, i.e. the part of the performance resulting from its division by the number of partners. Only the appropriate wording in the contract of principles governing the formulation of recourse claims will ensure that, finally, the sole person responsible for damage caused will be the inept lawyer who brought it about (Article 376 of the Civil Code).

In a registered partnership, the inept attorney will be accountable for damage only when the enforcement of damages from the assets of the company proves ineffective; even then, however, he shall be jointly and severally liable with the remaining partners. Any recourse by the company against an inept attorney would appear to be inadmissible. However, recourse-based liability between partners with reference to their subsidiary liability means - in principle - that they incur compensatory consequences in equal parts. The separate regulation in the contract of partnership of the said issue and the necessity of ensuring such a recourse-based settlement so that, effectively, the entirety of damages paid encumbers the inept attorney, may actually make a registered partnership more akin to a partnership, although in the latter in principle (without the necessity of formulating recourses) it is the inept partner who is solely liable for damage (although in this case, too, we are dealing with subsidiary liability). In the case of a limited partnership, the liability of a general partner is governed by the same principles as in a registered partnership.

Keywords: civil liability, attorney 